\title{
Dormancy and enzymatic activity of rice cultivars seeds stored in different environments ${ }^{1}$
}

\author{
Elizabeth Rosemeire Marques²*, Roberto Fontes Araújo ${ }^{3}$, Eduardo Fontes Araújo ${ }^{4}$, \\ Sebastião Martins Filho ${ }^{5}$, Plínio César Soares ${ }^{3}$, Eduardo Gomes Mendonça $^{6}$
}

\begin{abstract}
The objective of this study was to assess the dormancy and the enzymatic activity of seeds of rice cultivars during storage in different environments. After harvesting, the seeds of two rice cultivars (BRS Ourominas and BRSMG Caravera) were dried in the sun, to reach a moisture content around $13 \%$. Then, they were packed in paper and stored in four environments: $5 \pm$ $2{ }^{\circ} \mathrm{C} / 70 \pm 5 \% \mathrm{RH}, 12 \pm 2{ }^{\circ} \mathrm{C} / 70 \pm 5 \% \mathrm{RH}, 18 \pm 2{ }^{\circ} \mathrm{C} / 65 \pm 5 \% \mathrm{RH}$ and in a natural condition. Germination and enzymatic activity were assessed at the beginning and at 3, 6, 9 and 12 months of storage. The experiment was conducted in split subplots in a completely randomized design with three replications. The dormancy of seeds stored in the natural environment was exceeded in a shorter time than the dormancy of seeds stored in cold. Catalase and ascorbate peroxidase activity increased during the storage period, the most obviously in storage in natural environment to cultivate BRSMG Caravera. The activity of the enzyme $\alpha$-amylase decreased during the storage period.
\end{abstract}

Index terms: enzymes, germination, Oryza sativa L.

\section{Dormência e atividade enzimática de sementes de cultivares de arroz armazenadas em diferentes ambientes}

\begin{abstract}
RESUMO - O objetivo deste trabalho foi avaliar a dormência e a atividade enzimática de sementes de cultivares de arroz durante o armazenamento em diferentes ambientes. Após a colheita, as sementes das cultivares de arroz BRS Ourominas (várzea) e BRSMG Caravera (terras altas) foram secadas ao sol, até atingirem teor de água em torno de $13 \%$. Em seguida, foram acondicionadas em embalagem de papel e armazenadas em quatro ambientes: $5 \pm 2{ }^{\circ} \mathrm{C} / 70 \pm 5 \% \mathrm{UR}, 12 \pm 2{ }^{\circ} \mathrm{C} / 70 \pm 5 \% \mathrm{UR}, 18 \pm 2{ }^{\circ} \mathrm{C} / 65 \pm 5 \%$ UR e em condição natural. A germinação e a atividade enzimática foram avaliadas no início e aos 3, 6, 9 e 12 meses de armazenamento. $\mathrm{O}$ experimento foi realizado no esquema de parcelas subdivididas no delineamento inteiramente casualizado com três repetições. A dormência das sementes armazenadas em ambiente natural foi superada em menor tempo do que as sementes armazenadas em câmara fria. Houve aumento da atividade das enzimas catalase e ascorbato peroxidase, com maior evidência no armazenamento em ambiente natural, para a cultivar BRSMG Caravera. A atividade da enzima $\alpha$-amilase diminuiu durante o período de armazenamento.
\end{abstract}

Termos para indexação: enzimas, germinação, Oryza sativa L.

\section{Introduction}

Seed is one of the most important inputs in modern agriculture and, among the various stages through which it passes after harvest, storage is a compulsory step of a production program, assuming an important role, especially in Brazil, due to the tropical and subtropical climate conditions.

In the storage conditions, temperature and relative

${ }^{1}$ Submitted on 09/11/2014. Accepted for publication on 11/05/2014.

${ }^{2}$ Departamento de Ciências Florestais, Universidade Federal de Lavras, Caixa Postal 3037, 37200-000 - Lavras, MG, Brasil.

${ }^{3}$ Empresa de Pesquisa Agropecuária de Minas Gerais, Caixa Postal 216, 36571-000 - Viçosa, MG, Brasil.

${ }^{4}$ Departamento de Fitotecnia, Universidade Federal de Viçosa, 36570-000 Viçosa, MG, Brasil. humidity are key factors in maintaining seed quality (Tonin and Perez, 2006), influencing the speed of the biochemical processes and indirectly interfering in water content of seeds.

The process of deterioration in seeds comprises a sequence of biochemical and physiological changes initiated immediately after physiological maturity, which lead to reduced vigor, culminating in the loss of germination capacity.

Changes in physiology of the seeds are indirectly related

${ }^{5}$ Departamento de Estatística, Universidade Federal de Viçosa, 36570-000 Viçosa, MG, Brasil

${ }^{6}$ Departamento de Bioquímica Agrícola, Universidade Federal de Viçosa, 36570-000 - Viçosa, MG, Brasil.

*Corresponding author < bethagro@yahoo.com.br> 
to the integrity of their cell membranes (Carvalho et al., 2009), which, in turn, depend on the nature of the enzymes and structural proteins of each species. The enzymes have been used in the assessment of physiological and biochemical changes in stored seeds (Santos et al., 2004).

Under normal physiological conditions, the oxidative stress produced is fought by a complex antioxidant defense system, related to increased production and activation of enzymes, that catalyzes the conversion of the hydrogen peroxide $\left(\mathrm{H}_{2} \mathrm{O}_{2}\right)$ into water $\left(\mathrm{H}_{2} \mathrm{O}\right)$, protecting cells from oxidative damage (Scandalios, 2005).

During the process of seed deterioration, there is a decrease in enzyme activity by its progressive inactivation or reduction and stoppage of its synthesis (Marcos-Filho 2005). The reduction of catalase activity in seeds reduces respiratory capacity, decreasing the supply of energy (ATP) and similar for the germination (Demirkaya et al., 2010).

In seeds of Triticum aestivum, reduction activity of catalase enzymes and superoxide dismutase was observed during artificial aging, resulting in loss of viability (Lehner et al., 2008). For Medicago sativa L., reduction of seed vigor during artificial aging was associated with decreased activity of catalase, superoxide dismutase and peroxidase (Cakmak et al., 2010).

In the quality control program of companies producing seeds, monitoring the physiological potential of dormant rice seeds is a fundamental aspect. The behavior is differentiated according to the cultivar and the cultivation system, and the dormancy is more intense in the floodplain system (Roberts, 1963).

Among certain inhibitor chemicals, which can be detected on the coat (glumes) of the seeds (Ketring, 1997), the phenolic compounds are highlighted, besides the presence of oxidizing agents, which promote oxidation, with the decrease in the concentration of $\mathrm{O}_{2}$. Accordingly, the association of the phenolic compounds with a high respiratory activity in seed coat tissues limits the $\mathrm{O}_{2}$ availability to the embryo (Bewley and Black, 1994). Therefore, during storage of seeds for a certain period, there is the possibility of a slow and gradual diffusion of $\mathrm{O}_{2}$ into its interior, causing a gradual reduction in the amount of germination inhibitors, thereby favoring breaking dormancy and hence its germination (Olatoye and Hall, 1972).

In this context, the objective of this work was to assess the enzymatic activity and dormancy of seeds of rice cultivars of floodplains and uplands during storage under different conditions.

\section{Material and Methods}

The study was developed at the Department of Plant Science at Universidade Federal de Viçosa, Viçosa, MG, with seeds of the rice cultivars BRS Ourominas (floodplains) and BRSMG Caravera (uplands), which were produced by Empresa de Pesquisa Agropecuária de Minas Gerais (EPAMIG), in Lambari, MG, in harvest 2009/2010.

Immediately after the harvest, the seeds were threshed and dried in the sun until they reached a water content of around $13 \%$.

The seeds were stored in paper packing and stored in four environments: cold chamber $1\left(5 \pm 2{ }^{\circ} \mathrm{C}, 70 \pm 5 \%\right.$ of relative humidity), cold chamber $2\left(12 \pm 2{ }^{\circ} \mathrm{C}, 70 \pm 5 \%\right.$ of relative humidity), cold room $\left(18 \pm 2{ }^{\circ} \mathrm{C}, 65 \pm 5 \%\right.$ of relative humidity) and in a natural environment (without control of temperature and relative humidity). During storage, the monitoring of temperature and relative humidity of the natural environment was done (Figure 1).

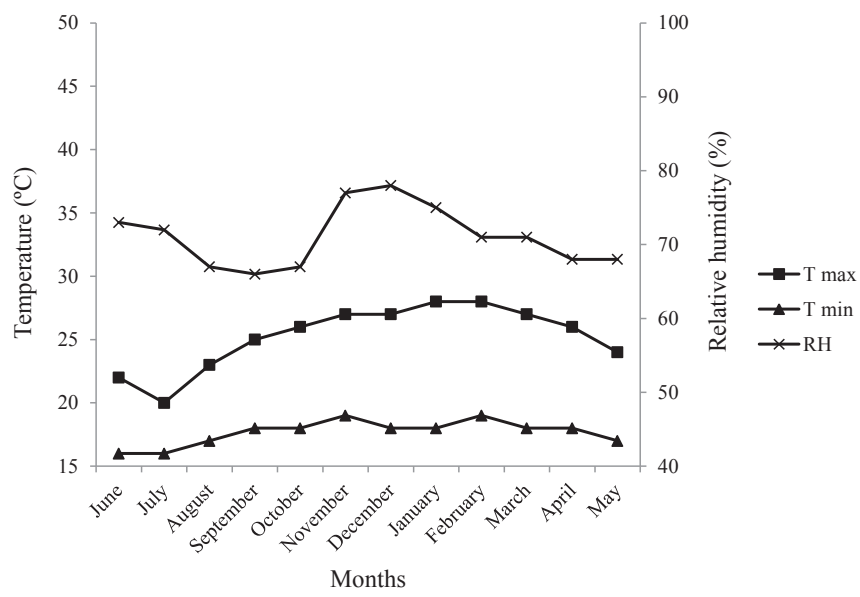

Figure 1. Monthly mean maximum ( $\mathrm{T} \max )$ and minimum temperatures ( $\mathrm{T} \mathrm{min}$ ) and relative humidity $(\mathrm{RH})$ in a natural environment, from June 2010 (beginning of the experiment) to May 2011 (end of the experiment).

Before storage and after 3, 6, 9 and 12 months the seeds were assessed according to the following methods:

Water content - it was determined by the oven method at $105 \pm 3{ }^{\circ} \mathrm{C}$ for 24 hours, using two samples of each treatment according to the Rules for Seed Analysis (Brasil, 2009). The results were expressed as percentages (wet basis).

Germination -four samples of 50 seeds per replication were used, treated with the fungicide Captan at a dose of $2.4 \mathrm{~g}$ of product per $\mathrm{kg}$ of seed. Then they were sown in (three sheets of) germitest paper moistened with distilled water in quantities equivalent to 2.5 times the weight of the dry paper. The rolls made were kept in a germinator at at $25^{\circ} \mathrm{C}$. Assessments were performed at 5 and 14 days after sowing, and the results were expressed as percentage of normal seedlings (Brasil, 2009). To do so, at the end of the tests, the seeds that remained 
dormant had their viability assessed by the tetrazolium test, according to criteria established by the Rules for Seed Testing (Brasil, 2009), to prove their dormancy.

Enzyme assays:for the extraction of catalase and ascorbate peroxidase, were used $2 \mathrm{~mL}$ of the phosphate buffer $50 \mathrm{mM}, \mathrm{pH} 7.8$ and $0,02 \mathrm{~g}$ of Polyvinylpolypyrrolidone (PVPP), and for $\alpha$-amylase, were used $2 \mathrm{~mL}$ of the sodium phosphate buffer $0.02 \mathrm{M}, \mathrm{pH} 6.9$ which were added to 0.2 $\mathrm{g}$ of crushed seed ice using mortar and pestle. Then the extract was centrifuged at $17,000 \mathrm{xg}$ for 30 minutes at $4{ }^{\circ} \mathrm{C}$. The supernatant was used for determination of enzyme activity and quantification of proteins. Catalase activity (CAT):enzyme activity was determined by assay containing $150 \mu \mathrm{L}$ of crude enzyme extract and $1350 \mu \mathrm{L}$ of a reaction medium consisting of: $850 \mu \mathrm{L}$ of phosphate buffer 50 $\mathrm{mM}, \mathrm{pH} 7.8$ and $500 \mu \mathrm{L}$ of $\mathrm{H}_{2} \mathrm{O}_{2} 0,97 \mathrm{M}$. The decrease in absorbance at $240 \mathrm{~nm}$ at a temperature of $25{ }^{\circ} \mathrm{C}$ was measured for 2 minutes of reaction, and the CAT activity was determined using the slope of the line after the start of the reaction. Ascorbate peroxidase activity (APX):enzyme activity was determined by assay containing $100 \mu \mathrm{L}$ of crude enzyme extract and $1400 \mu \mathrm{L}$ of a reaction medium consisting of: $700 \mu \mathrm{L}$ of phosphate buffer $50 \mathrm{mM}, \mathrm{pH} 7.6$, $400 \mu \mathrm{L}$ of ascorbic acid $0.25 \mathrm{mM}$ containing EDTA $0.1 \mathrm{mM}$, and $300 \mu \mathrm{L}$ of $\mathrm{H}_{2} \mathrm{O}_{2} 0,3 \mathrm{mM}$. The decrease in absorbance at $290 \mathrm{~nm}$ at a temperature of $25^{\circ} \mathrm{C}$ was measured during 2 minutes, and the APX activity was determined based in the inclination of the line after the reaction beginning.

Activity of $\alpha$-amylase: enzyme activity was determined by the formation of reducing sugars from starch using the DNS reagent, by the test containing in glass tubes $50 \mu \mathrm{L}$ of the enzyme extract and $450 \mu \mathrm{L}$ of starch $1 \%$; after a five-minute reaction $500 \mu \mathrm{L}$ of the solution of the dinitrosalicylic acid were added -3.5 ; then the tubes were placed to boil for five minutes. After cooling, $3 \mathrm{~mL}$ of deionized water were added to all. The reading was performed at a wavelength of $540 \mathrm{~nm}$.

Statistical design - the experiment was conducted using a completely randomized design with three replications in a split subplot design. The environment factor was applied to the plots, cultivars in the subplots and storage time in the subsubplots. In the analysis of variance, regardless of significance, deploying the environment $\mathrm{x}$ cultivar $\mathrm{x}$ storage interaction was chosen. The levels of environment factors and cultivars were compared by Tukey test (5\%) and the storage factor was subjected to a regression analysis. For data analysis, the Sistema de AnálisesEstatísticas e Genéticas (Statistical and Genetic Analysis System) - SAEG was used (SAEG, 2007).

\section{Results and Discussion}

In the characterization of germination and seed dormancy of rice cultivars recently harvested it was noted, by the tetrazolium test, a higher percentage of dormancy in the cultivar of floodplains BRS Ourominas (17\%) and only 5\% of dormant seeds in cultivar BRSMG Caravera (Table 1). Thus, it is possible to consider that after breaking dormancy, germination of the lot of both cultivars will be above $80 \%$, which is a minimum standard for marketing rice seeds. The remaining seeds that did not germinate in the germination test were dead.

Table 1. Results of germination and seed dormancy of rice cultivars before storage.

\begin{tabular}{ccc}
\hline Cultivars & Germination (\%) & Dormancy (\%) \\
\hline BRS Ourominas & $69 \mathrm{~B}$ & $17 \mathrm{~A}$ \\
BRSMG Caravera & $75 \mathrm{~A}$ & $5 \mathrm{~B}$ \\
\hline
\end{tabular}

Means followed by the same letter do not differ significantly at 5\%probability by Tukey test.

The contents of the initial water of the seeds were $13.6 \%$ (cultivar BRS Ourominas) and 13.3\% (cultivar BRSMG Caravera), practically similar (Table 2). During storage, the variation in water content was less than $1 \%$, suggesting that for different storage conditions the initial water content of the seeds of cultivars was close to the moisture equilibrium. The water content of the seeds was similar among cultivars, environment and storage periods. Consequently, only the effect of storage temperatures on physiological quality and enzyme activity of the seeds during storage was considered.

Analyzing the results of germination (Figure 2) on seeds stored at $5{ }^{\circ} \mathrm{C}, 12{ }^{\circ} \mathrm{C}, 18{ }^{\circ} \mathrm{C}$ and in a natural environment, it was found that the maximum germination for cultivar BRS Ourominas was $85 \%$ at 6.1 months, $83 \%$ at 6.4 months, $85 \%$ at 6.9 months and $80 \%$ at 3.5 months, respectively.

In general, the sharpest increase in seed germination of cultivar BRS Ourominas during the first six months of storage under different conditions is probably due to the fact that this cultivar has a higher percentage of dormant seeds (Table 1). The results suggest that the dormancy of cultivar BRS Ourominas has been overcome between 6 and 7 months of storage in seeds stored at controlled temperatures $(5,12$ and $18{ }^{\circ} \mathrm{C}$ ) (Figure 2). For the seeds of this cultivar stored under natural conditions, breaking dormancy has occurred early, at 3.5 months of storage (Figure 2); probably the alternating temperatures and the storage average maximum temperatures near $25^{\circ} \mathrm{C}$ (Figure 1) have accelerated the process of breaking dormancy. 
Table 2. Water content (\%) of seeds of rice cultivars during storage under different environmental conditions.

\begin{tabular}{|c|c|c|c|}
\hline \multirow{2}{*}{$\begin{array}{l}\text { Storage time } \\
\text { (months) }\end{array}$} & \multirow{2}{*}{ Environments } & \multicolumn{2}{|c|}{ Cultivars } \\
\hline & & BRS Ourominas & BRSMG Caravera \\
\hline \multirow{4}{*}{0} & $5{ }^{\circ} \mathrm{C} / 70 \% \mathrm{RU}$ & $13.6 \mathrm{aA}^{1}$ & $13.3 \mathrm{aB}$ \\
\hline & $12^{\circ} \mathrm{C} / 70 \% \mathrm{RU}$ & $13.6 \mathrm{aA}$ & $13.3 \mathrm{aB}$ \\
\hline & $18^{\circ} \mathrm{C} / 65 \% \mathrm{RU}$ & $13.6 \mathrm{aA}$ & $13.0 \mathrm{bB}$ \\
\hline & Natural & $13.6 \mathrm{aA}$ & $13.3 \mathrm{aB}$ \\
\hline \multirow{4}{*}{3} & $5^{\circ} \mathrm{C} / 70 \% \mathrm{RU}$ & $13.0 \mathrm{bA}$ & $12.8 \mathrm{cB}$ \\
\hline & $12{ }^{\circ} \mathrm{C} / 70 \% \mathrm{RU}$ & $12.9 \mathrm{cA}$ & $12.9 \mathrm{cA}$ \\
\hline & $18^{\circ} \mathrm{C} / 65 \% \mathrm{RU}$ & $12.9 \mathrm{cB}$ & $13.1 \mathrm{bA}$ \\
\hline & Natural & $13.5 \mathrm{aA}$ & $13.3 \mathrm{aB}$ \\
\hline \multirow{4}{*}{6} & $5{ }^{\circ} \mathrm{C} / 70 \% \mathrm{RU}$ & $12.9 \mathrm{bB}$ & $13.6 \mathrm{aA}$ \\
\hline & $12{ }^{\circ} \mathrm{C} / 70 \% \mathrm{RU}$ & $13.5 \mathrm{aB}$ & $13.7 \mathrm{aA}$ \\
\hline & $18^{\circ} \mathrm{C} / 65 \% \mathrm{RU}$ & $13.5 \mathrm{aA}$ & $12.6 \mathrm{bB}$ \\
\hline & Natural & $13.5 \mathrm{aB}$ & $13.6 \mathrm{aA}$ \\
\hline \multirow{4}{*}{9} & $5{ }^{\circ} \mathrm{C} / 70 \% \mathrm{RU}$ & $14.0 \mathrm{bB}$ & $14.6 \mathrm{aA}$ \\
\hline & $12^{\circ} \mathrm{C} / 70 \% \mathrm{RU}$ & $14.0 \mathrm{bB}$ & $14.2 \mathrm{cA}$ \\
\hline & $18^{\circ} \mathrm{C} / 65 \% \mathrm{RU}$ & $13.6 \mathrm{cB}$ & $13.8 \mathrm{dA}$ \\
\hline & Natural & $14.6 \mathrm{aA}$ & $14.4 \mathrm{bB}$ \\
\hline \multirow{4}{*}{12} & $5{ }^{\circ} \mathrm{C} / 70 \% \mathrm{RU}$ & $13.6 \mathrm{bB}$ & $14.2 \mathrm{aA}$ \\
\hline & $12{ }^{\circ} \mathrm{C} / 70 \% \mathrm{RU}$ & $13.6 \mathrm{bB}$ & $13.8 \mathrm{cA}$ \\
\hline & $18{ }^{\circ} \mathrm{C} / 65 \% \mathrm{RU}$ & $13.3 \mathrm{cB}$ & $13.4 \mathrm{dA}$ \\
\hline & Natural & $14.1 \mathrm{aA}$ & $14.0 \mathrm{bB}$ \\
\hline
\end{tabular}

${ }^{1}$ Means followed by the same lowercase letter in the column and uppercase letter in the line do not differ significantly at $5 \%$ probability by Tukey test.
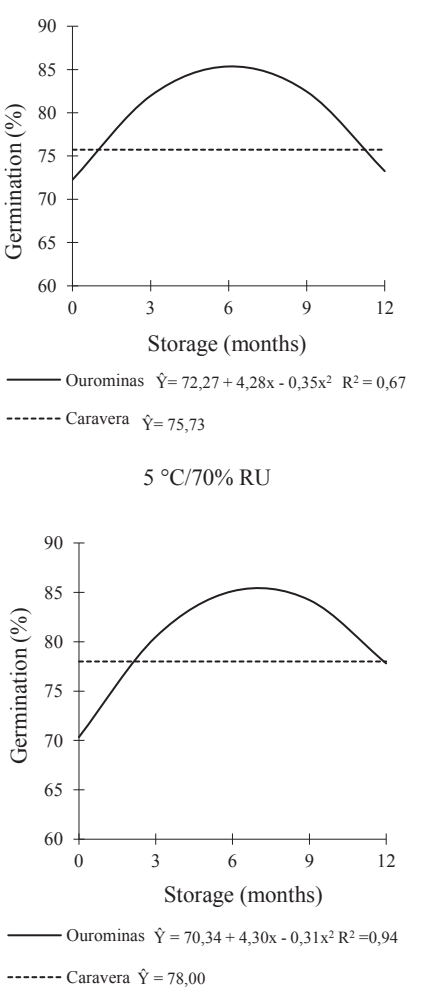

$18{ }^{\circ} \mathrm{C} / 65 \% \mathrm{RU}$
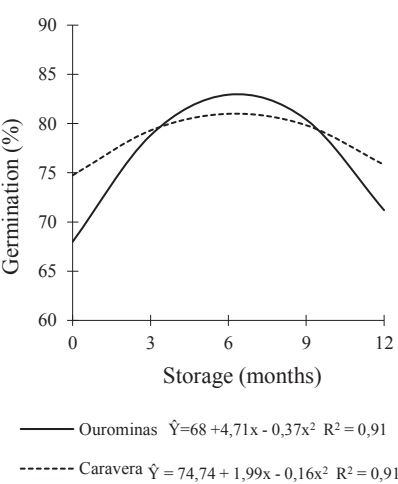

$12{ }^{\circ} \mathrm{C} / 70 \% \mathrm{RU}$

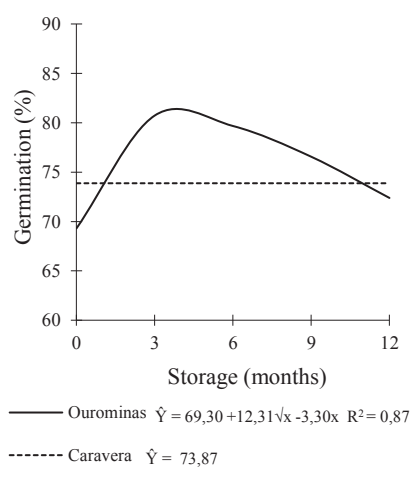

Natural environment

Figure 2. Germination of seeds of rice cultivars during storage in different environments.

Vieira et al. (2008) also found that rice seeds of irrigated cultivar Rio Grande stored in conventional environment in Lavras, MG, with a temperature between 15 and $28{ }^{\circ} \mathrm{C}$ and relative humidity ranging between 60 and $72 \%$, have broken dormancy more rapidly during storage than stored seeds in a cold and dry room. These results show that seed dormancy decreases over the storage period, especially with increasing temperature.

The seeds of cultivar BRSMG Caravera have not had their germination reduced by storage at $5{ }^{\circ} \mathrm{C}, 18{ }^{\circ} \mathrm{C}$ and natural environment. At $12{ }^{\circ} \mathrm{C}$, germination increased to 6.2 months of storage, suggesting that breaking dormancy (Figure 2) has occurred.

Only the seeds of cultivar BRS Ourominas, regardless of the environment, have maintained germination above the minimum required for commercialization until six months of storage.

In situations where there has been breaking dormancy, regardless of cultivar and the storage environment after reaching the maximum germination, a process of natural seed deterioration with a consequent reduction in germination vigor has begun.

Marques et al. (2014) have observed similar results studying three rice cultivars stored in four storage environments, namely, loss of germination vigor after reaching maximum germination and vigor. Macedo et al. (1999) when assessing rice seeds of cultivar IAC 165, stored for 12 months in Campinas, SP, with 
a relative humidity of $72 \%$ and an average temperature of $21{ }^{\circ} \mathrm{C}$, have observed a gradual decrease in germination from the eighth month.

Theoretically, the deterioration starts at physiological maturity; however, it is most frequently detected during storage. Once the seed has reached a maximum physiological quality, namely, the point of maximum germination, vigor, and dry matter accumulation, a continuous and irreversible process of deterioration begins. The process of deterioration in seeds comprises a sequence of biochemical and physiological changes initiated immediately after physiological maturity, which lead to reduced vigor, culminating in the loss of germination capacity. This process cannot be avoided, but can be slowed down when the storage is done under favorable conditions, especially of temperature and relative humidity.

In this work, as the relative humidity of the storage environment was similar, reflecting in seeds with water content with little variation throughout the storage period (Table 1), the difference in seed germination was attributed to differences in temperatures. In general, seeds stored in room temperatures of 5, 12 and $18^{\circ} \mathrm{C}$ have shown, at the end of storage, greater germination than the seeds stored in a natural environment. In this environment, for eight months of storage, temperatures above $25{ }^{\circ} \mathrm{C}$ could be seen, which certainly contributed to a further deterioration of seeds. The temperature significantly contributes to the conservation of seeds, directly affecting the speed of the biochemical processes, which also trigger other processes such as increasing the enzymatic activity (hydrolytic enzymes) and free fatty acids (Schwember and Bradford, 2010).

As to catalase enzyme activity (Figure 3), in the environment at $5{ }^{\circ} \mathrm{C}$ it was observed, in the seeds of cultivar BRS Ourominas, a linear increase in catalase activity during the storage period and, for seeds of cultivar BRSMG Caravera, an increased activity during the storage period corresponded to the square root model. At $12{ }^{\circ} \mathrm{C}$ it was found in the seeds of cultivar BRS Ourominas a gradual increase in the enzyme activity up to approximately nine months, followed by a larger increase until 12 months. In the seeds of cultivar BRSMG Caravera, the sharpest increase in activity began close to three months of storage and additions up to 12 months could be seen. At $18{ }^{\circ} \mathrm{C}$, for both cultivars, the increase was gradual until about nine months, with highest increases at 12 months. In the natural environment, for the seeds of cultivar BRS Ourominas, enzyme activity remained at low levels until approximately six months, followed by a small increase up to 12 months of storage. For the seeds of cultivar BRSMG Caravera, there was a greater increase from approximately three months with increase up to 12 months of storage. Clearly, the longer the storage time, the greater the catalase activity in seeds of rice cultivars for all treatments.

The increase in catalase activity has been related to the production of $\mathrm{H}_{2} \mathrm{O}_{2}$ in conditions of oxidative stress (Nasr et al., 2011). This result can be compared with the results of germination (Figure 2) during the storage period of rice seeds, namely, an advancement in the deteriorating process, with loss of germination, and the enzyme thereby acting as a protection mechanism. To prevent irreversible cell damage, enzymes of the antioxidant system get into action when levels of ROS (reactive oxygen species), preventing their formation and promoting the removal of reactive forms produced, exceed certain levels, according to each species (Moller et al., 2007 and Scandalios, 2005).
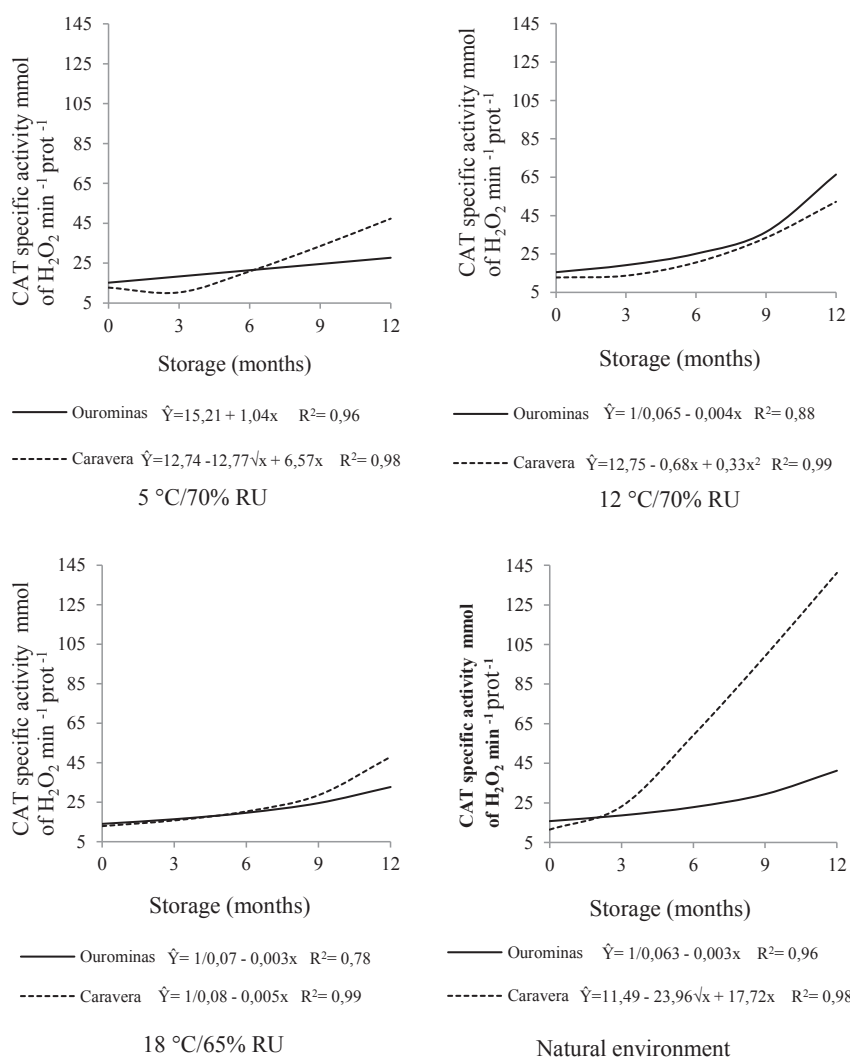
$12{ }^{\circ} \mathrm{C} / 70 \% \mathrm{RU}$

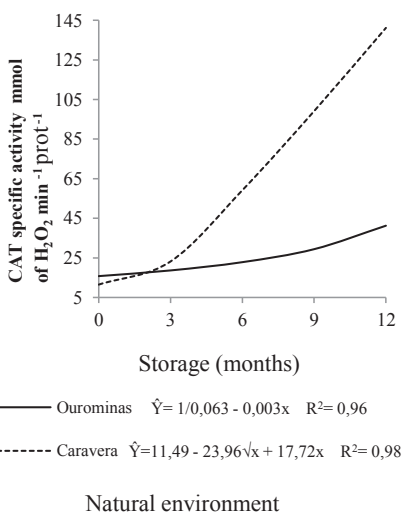

Figure 3. Specific activity of the catalase enzyme (CAT) (mmol of $\mathrm{H}_{2} \mathrm{O}_{2} \min ^{-1} \mu \mathrm{g}$ of prot $^{-1}$ ) in rice cultivar seeds during storage in different environments.

Nonetheless, Yin et al. (2014) have observed in artificially aged rice seeds of Oryza sativa L. cv. (Wanhua number 11) a decreased catalase activity, resulting in a drop in the percentage of germination from 99 to $2 \%$. Similar results were found by Chauhan et al. (2011), where the decrease of the activities of catalase and peroxidase in Triticum aestivum seeds during aging have resulted in lower viability and vigor.

The ascorbate peroxidase enzyme activity (Figure 4) at 
the environment of $5{ }^{\circ} \mathrm{C}$ in seeds of two cultivars has linearly increased during storage. In the environment of $12{ }^{\circ} \mathrm{C}$, in the seeds of cultivar BRSMG Caravera, it was observed that the activity of the enzyme remained at low levels during storage, and in the seeds of cultivar BRS Ourominas there was no difference during storage. At the environment of 18 ${ }^{\circ} \mathrm{C}$ in seeds of cultivar BRS Ourominas an increased activity during storage was observed, and in the seeds of cultivar Caravera there was no difference during storage. In the natural environment, for seeds of cultivar Ourominas, activity remained at low levels until approximately six months, followed by a slight increase up to 12 months. In cultivar BRSMG Caravera, the increase was very sharp from the three months of storage. These results demonstrate that an increased oxidative stress has occurred in this environment; therefore, there was a higher activity of catalase enzymes and ascorbate peroxidase.
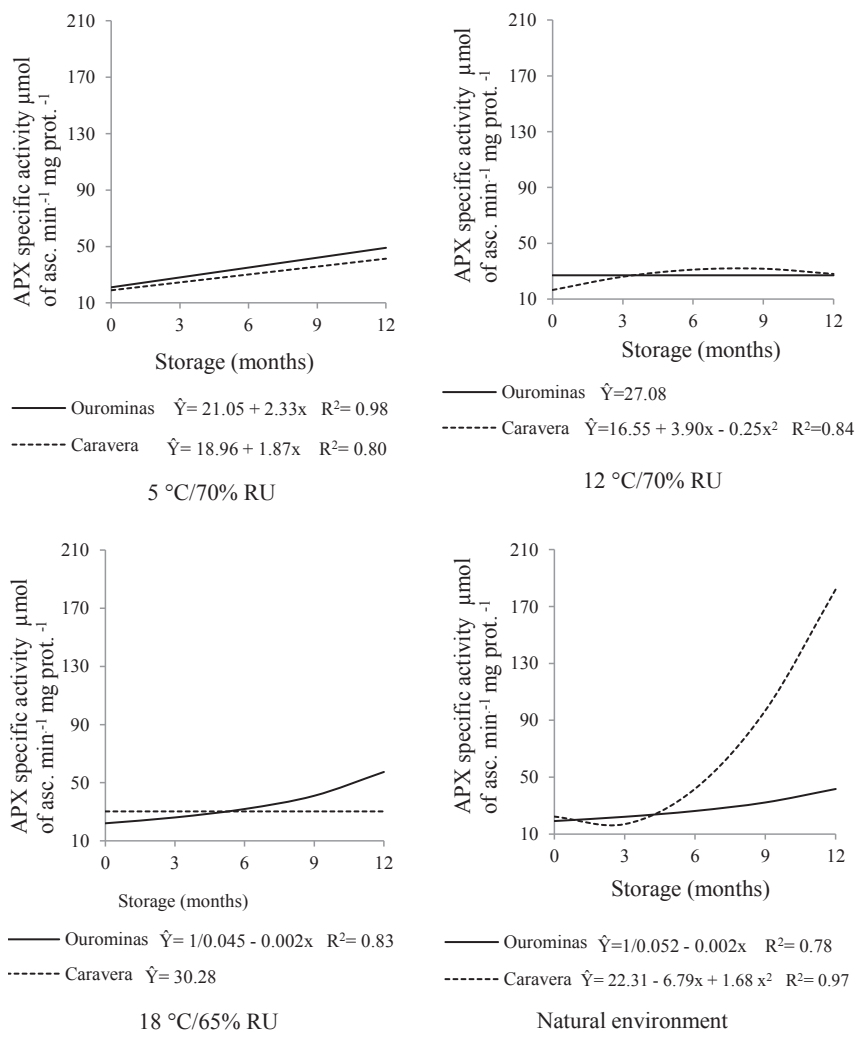

Figure 4. Specific activity of the enzyme ascorbate peroxidase (APX) ( $\mu$ mol de asc $\min ^{-1} \mu \mathrm{g}$ of prot $^{-1}$ ) in seeds of rice cultivars during storage in different environments.

Similar studies have been reported relating the increase of APX activity in different stress conditions on sunflower seeds (Carneiro et al., 2011) and bean seeds (Deuner et al., 2011).
However, Yin et al. (2014) have observed in artificially aged rice seeds of Oryza sativa L. cv. (Wanhua number 11), a reduction of ascorbate peroxidase activity, resulting in loss of seed viability.

The activity of the enzyme ascorbate peroxidase during storage in both cultivars, has shown a lower level than the route of catalase. The performance of the routes, involving the catalase and ascorbate peroxidase, is simultaneous, which can result in low activity for both, but performing an efficient detoxification. With the advancement in the process of deterioration during storage, an accumulation of toxic levels of $\mathrm{H}_{2} \mathrm{O}_{2}$ can occur in plant tissues. Different types of stresses may result in the combined action of CAT and APX to protect cells from the action of peroxides. However, these two enzymes have different affinities for $\mathrm{H}_{2} \mathrm{O}_{2}$. The APX has a high affinity (range $\mu \mathrm{M}$ ), being responsible for the fine modulation in levels of EROs (Mittler, 2002).

However, it is necessary to emphasize that the in vitro enzymatic activities are limited because the activities in the tissue in vivo may be different because the plant is in other conditions. The in vitro antioxidant capacity assays are important to check whether there is or not a correlation between the antioxidants and the levels of oxidative stress (Huang et al., 2005).

By the $\alpha$-amylase enzyme activity (Figure 5), it was observed, in the four environments, that the two cultivars have shown the same behavior, namely, a drastic reduction close to six months of storage, showing an exponential model. A small percentage of dormancy observed in the seeds of cultivars (Table 1), 17\% in the seeds of BRS Ourominas and 5\% in BRSMG Caravera, may be the reason for the high activity of $\alpha$-amylase in the beginning of the storage period.

Livesley and Bray (1991); Vieira et al. (2008) have reported that in seeds with high dormancy, the activity of $\alpha$-amylase has been little. Shaw and Ou-Lee, cited by Das and Sen-Mandi (1992), have reported that the $\alpha$-amylase activity is essential for the germination of the rice seeds.

During the storage period, there was a reduced activity of $\alpha$-amylase in the different environments. This result can be compared with the results of decrease of germination (Figure 2), namely, an advancement in the deteriorating process and a reduced activity of this enzyme. Decline in $\alpha$-amylase activity has been reported in cereal seeds after aging. Ganguli and Sen-Mandi (1993) have observed that the scutellar amylase activity in wheat seeds was reduced in aged seeds. Livesley and Bray (1991) have observed that the $\alpha$-amylase enzyme was synthesized at rates reduced by the aleurone layer of aged wheat seeds. According to the authors, the process of deterioration can interfere with enzymes in the aleurone layer during aging. Such changes may influence the production of $\alpha$-amylase which, in turn, may interfere in germination. 

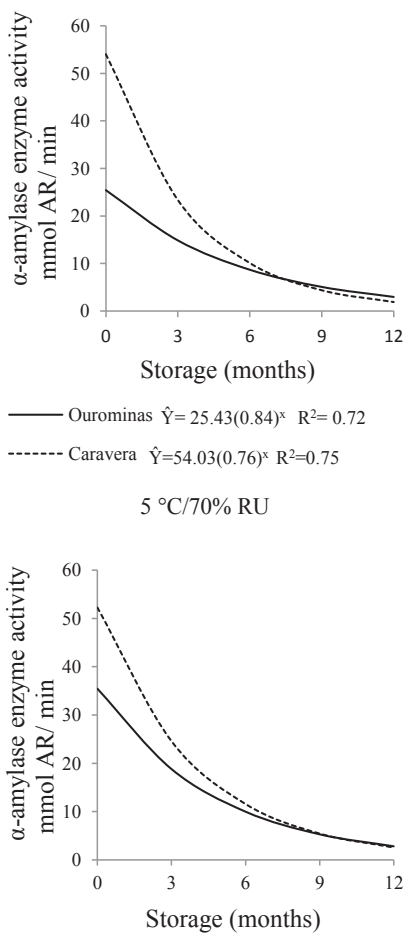

- Ourominas $\hat{\mathrm{Y}}=35.45(0.81)^{\mathrm{x}} \quad \mathrm{R}^{2}=0.62$

----- Caravera $\hat{\mathrm{Y}}=52.26(0.78)^{\mathrm{x}} \quad \mathrm{R}^{2}=0.77$

$18{ }^{\circ} \mathrm{C} / 65 \% \mathrm{RU}$
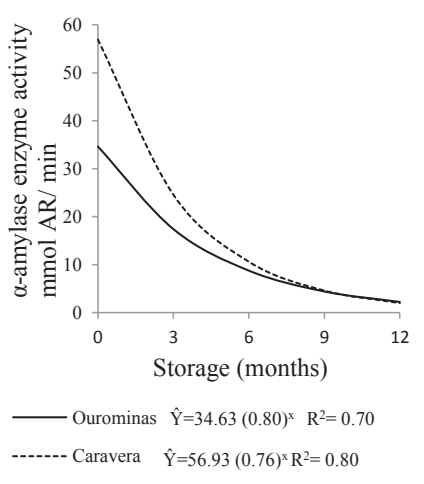

$12{ }^{\circ} \mathrm{C} / 70 \% \mathrm{RU}$

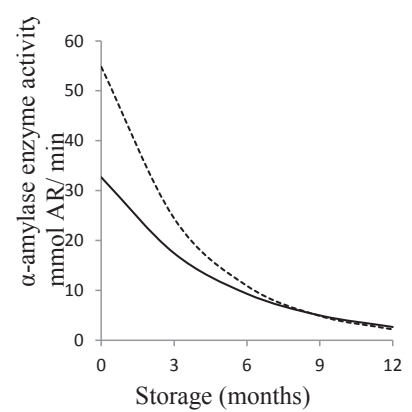

- Ourominas $\hat{\mathrm{Y}}=32.65(0.81)^{\mathrm{x}} \mathrm{R}^{2}=0.61$

------ Caravera $\hat{Y}=54.78(0.76)^{x} R^{2}=0.73$

Natural environment

Figure 5. Activity of $\alpha$-amylase enzyme (mmol of reducing sugar/min) in seeds of rice cultivars during storage in different environments.

\section{Conclusions}

The dormancy of seeds stored in the natural environment was surpassed by the shorter storage of seeds in cold room;

There was an increased activity of catalase and ascorbate peroxidase, most obviously in the seeds of cultivar BRSMG Caravera stored in a natural environment;

The activity of $\alpha$-amylase enzyme has decreased during the storage period.

\section{Acknowledgments}

To CNPq for the doctoral scholarship to the first author and to FAPEMIG, for the financial support for the research project.

\section{References}

BEWLEY, J.D.; BLACK, M. Seeds: physiology of development and germination. New York: Plenum Press, 1994. 445p.

BRASIL. Ministério da Agricultura, Pecuária e Abastecimento. Regras para análise de sementes. Ministério da Agricultura, Pecuária e Abastecimento. Secretaria de Defesa Agropecuária. Brasília: MAPA/ACS, 2009. 395p.http:// www.agricultura.gov.br/arq_editor/file/2946_regras_analise_sementes.pdf

CAKMAK, T.; ATICI, O.; AGAR, G.; SUNAR, S. Natural aging-related biochemical changes in alfafa (Medicago sativa L.) seeds stored for 42 years. International Research Journal of Plant Science, v.1, n.1, p.1-6, 2010.

CARNEIRO, M.M.L.C.; DEUNER, S.; OLIVEIRA, P.V.; TEIXEIRA, S.B.; SOUSA, C.P.; BACARIN, M.A.; MORAES, D.M. Atividade antioxidante e viabilidade de sementes de girassol após estresse hídrico e salino. Revista Brasileira de Sementes, v.33, n.4, p.754-763, 2011.www.scielo.br/pdf/rbs/ v33n4/17.pdf

CARVALHO, L.F.; SEDIYAMA, C.S.; REIS, M.S.; DIAS, D.C.F.S.; MOREIRA, M.A. Influência da temperatura de embebição da semente de soja no teste de condutividade elétrica para avaliação da qualidade fisiológica. Revista Brasileira de Sementes, v.31, n.1, p.9-17, 2009.www.scielo.br/pdf/ rbs/v31n1/a01v31n1.pdf

CHAUHAN, D.S.; DESWAL, D.P.; DAHIYA, D.P.; PUNIA, R.C. Change in storage enzymes activities in natural and accelerated aged seed of wheat (Triticumaestivum). Indian Journal of Agricultural Sciences, v.81, n.11, p.1037-1040, 2011.

DAS, G.; SEN-MANDI, S. Scutellar amylase activity in naturally aged accelerated aged wheat seeds. Annals of Botany, v.69, n.6, p.497-501, 1992.

DEMIRKAYA, M.; DIETZ, K.J.; SIVRITEPE, H.O. Changes in antioxidant enzymes during aging of onion seeds. Notulae Botanicae Horti Agrobotanici, v.38, n.1, p.49-52, 2010. <http://notulaebotanicae.ro/nbha/ article/viewPDFInterstitial/4575/4417>

DEUNER, C.; MAIA, M.S.; DEUNER, S.; ALMEIDA, A.S.; MENEGHELLO, G.E. Viabilidade e atividade antioxidante de sementes de genótipos de feijão-miúdo submetidos ao estresse salino. Revista Brasileira de Sementes, v.33, n.4, p.711-720, 2011. www.scielo.br/pdf/rbs/v33n4/13.pdf

GANGULI, S.; SEN-MANDI, S. Effects of aging on amylase activity and scutellar cell structure during imbibition in wheat seed. Annals of Botany, v.71, n.5, p.411-416, 1993.

HUANG, D.; OU, B.; PRIOR, R.L. The chemistry behind antioxidant capacity assays. Journal of Agricultural and Food Chemistry, v.53, n.6, p.1841-1856, 2005.http://pubs.acs.org/doi/abs/10.1021/jf030723c

KETRING, A.L. Germination inhibitors. Seed Science and Technology, v.1, n.2, p.305-324, 1997.

LEHNER, A.; MAMADOU, N.; POELS, P.; CÔME, D.; BAIlly, C.; CORBINEAU, F. Changes in soluble carbohydrates, lipid peroxidation and antioxidant enzyme activities in the embryo during aging in wheat grains. Journal of Cereal Science, v.47, n.3, p.555-565, 2008. http://www. sciencedirect.com/science/article/pii/S0733521007001312

LIVESLEY, M.A.; BRAY, C.M. The effect of aging upon $\alpha$-amylase production and protein synthesis by wheat aleurone layers. Annals of Botany, v.68, n.1, p.69-73, 1991 .

MACEDO, E.C.; GROTH, D.; SOAVE, J. Influência da embalagem e do armazenamento na qualidade fisiológica de sementes de arroz. Revista Brasileira de Sementes, v.21, n.1, p.67-75, 1999. www.abrates.org.br/revista/ artigos/1999/v21n1/artigo10.pdf

MARCOS-FILHO, J. Fisiologia de sementes de plantas cultivadas Piracicaba: FEALQ, 2005. 495p. 
MARQUES, E.R.; ARAÚJO, E.F.; ARAÚJO, R.F.; FILHO, S.M.; SOARES, P.C. Seed quality of rice cultivars stored in different environments. Journal of Seed Science, v.36, n.1, p.32-39, 2014.www.readcube.com/articles/10.1590/ S2317-15372014000100004

MITTLER, R. Oxidative stress, antioxidants and stress tolerance. Trends in Plant Science, v.7, n.9, p.405-410, 2002.

MOLLER, I.M.; JENSEN, P.E.; HANSSON, A. Oxidative modifications to cellular components in plants. Annual Review of Plant Biology, v.58, p.459-481， 2007.http://www.annualreviews.org/doi/abs/10.1146/annurev. arplant.58.032806.103946

NASR, N.; CARAPETIAN, J.; HEIDARI, R.; ASRI REZAEI, S.; ABBASPOUR, N.; DARVISHZADEH, R.; GHEZELBASH, F. The effect of aluminum on enzyme activities in two wheat cultivars. African Journal of Biotechnology, v.10, n.17, p.3354-3364, 2011. http://www.ajol.info/index. php/ajb/article/viewFile/93401/82812

OLATOYE, S.T.; HALL, M.A. Interaction of ethylene and light on dormant weed seeds. In: HEYDECKER, W. (Ed.). Seed Ecology, Norwich: Pennsylvania State University, 1972. p.233-249.

ROBERTS, E.H. An investigation of inter varietal differences in dormancy and viability of rice seed. Annals of Botany, v.27, n.2, p.365-369, 1963

SAEG - Sistema para Análises Estatísticas, Versão 9.1: Fundação Arthur Bernardes - UFV - Viçosa, 2007.www.ufv.br/saeg/download.htm

SANTOS, C.M.R.; MENEZES, N.L.; VILLELA, F.A. Alterações fisiológicas e bioquímicas em sementes de feijão envelhecidas artificialmente. Revista Brasileira de Sementes, v.26, n.1, p.110-119, 2004. www.scielo.br/scielo. php?script $=$ sci_arttext $\&$ pid $=\mathrm{S} 0101$
SCANDALIOS, J.G. Oxidative stress: molecular perception and transduction of signals triggering antioxidant gene defenses. Brazilian Journal of Medical and Biological Research, v.38, n7, p. 995 -1014, 2005. http://www.scielo. br/scielo.php?pid=S0100-879X2005000700003\&script=sci_arttext\&tlng=pt

SCHWEMBER, A.; BRADFORD, K.J. Quantitative trait loci associated with longevity of lettuce seeds under conventional and controlled deterioration storage conditions. Journal of Experimental Botany, v.61, n.15, p.4423-4436, 2010. http://jxb.oxfordjournals.org/content/early/2010/08/06/jxb.erq248.short

TONIN, G.A.; PEREZ, S.C.J.G.A. Qualidade fisiológica de sementes de Ocotea porosa (Nees et Martius ex. Nees) após diferentes condições de armazenamento e semeadura. Revista Brasileira de Sementes, v.28, n.2, p.2633, 2006. www.readcube.com/articles/10.1590/S0101-31222006000200004

VIEIRA, A.R.; OLIVEIRA, J.A.; GUIMARÃES, R.M.; VON PINHO, E.V.R.; PEREIRA, C.E.; CLEMENTE, A.C.S. Marcador isoenzimático de dormência em sementes de arroz. Revista Brasileira de Sementes, v.30, n.1, p.81-89, 2008. www.scielo.br/scielo.php?pid=S0101-31222008000100011\&script

YIN, G.; XIN, X.; SONG, C.; CHEN, X.; ZHANG, J.; WU, S.; LI, R.; LIU, $\mathrm{X}$; LU, X. Activity levels and expression of antioxidant enzymes in the ascorbate-glutathione cycle in artificially aged rice seed. Plant Physiology and Biochemistry, v.80, p.1-9, 2014. www.sciencedirect.com/.../pii/ S0981942814000849 